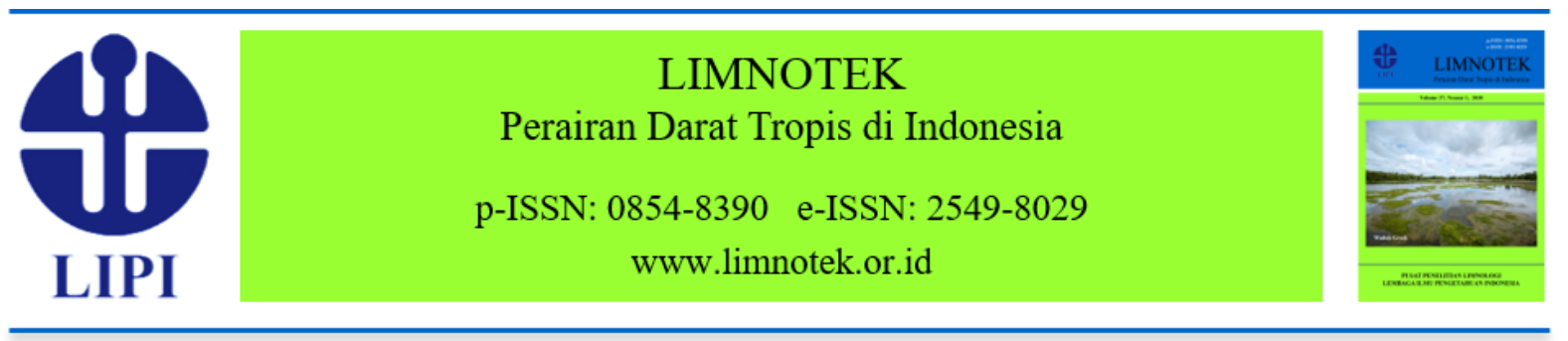

\title{
Status Pencemaran Situ Gunung Putri di Kabupaten Bogor Berdasarkan Metode STORET dan Indeks Pencemaran
}

\author{
Mira Aristawidya ${ }^{1},{\text { Zahidah } \text { Hasan }^{1} \text {, Iskandar }}^{1}$, Yustiawati $^{2}$, Heti Herawati ${ }^{1}$ \\ ${ }^{1}$ Program Studi Perikanan FPIK Unpad, \\ ${ }^{2}$ Pusat Penelitian Limnologi, Lembaga Ilmu Pengetahuan Indonesia (LIPI)
}

Email: mirarista21@gmail.com

Diajukan 5 Oktober 2019. Ditelaah 25 Februari 2020. Disetujui 27 Juni 2020.

\begin{abstract}
Abstrak
Situ Gunung Putri yang terletak di Kabupaten Bogor berfungsi untuk menampung air, irigasi pertanian, kegiatan perikanan, serta tempat pembuangan limbah domestik dan industri. Aktivitas masyarakat di sekitar situ diduga menyebabkan penurunan kualitas fisika, kimia, dan biologi perairan situ. Oleh karena itu, penelitian mengenai status pencemaran perlu dilakukan untuk pengelolaan sumber daya perairan situ. Tujuan penelitian ini adalah untuk mengetahui status pencemaran Situ Gunung Putri yang diukur dari parameter fisika dan kimia perairannya. Penelitian dilaksanakan dari bulan Februari sampai Maret 2019. Metode yang digunakan dalam penentuan status pencemaran yaitu metode STORET dan Indeks Pencemaran (IP). Hasil pengukuran kualitas air yang dilakukan di lapangan dibandingkan dengan baku mutu air, dan digunakan dalam penentuan status pencemaran menurut masingmasing metode. Kedua metode menghasilkan status kualitas air yang berbeda untuk masingmasing stasiun, dengan skor metode STORET berkisar -20-0 dan skor metode Indeks Pencemaran berkisar 0,31-3,92. Metode STORET lebih akurat menjelaskan kondisi pencemaran di Situ Gunung Putri dan menunjukkan air situ dalam kondisi tercemar ringan hingga sedang. Berdasarkan kedua metode yang digunakan, status pencemaran tertinggi ditemukan di Stasiun 3 dan 5. Bahan organik dengan kandungan yang tinggi diduga sebagai penyebab pencemaran karena parameter kualitas air yang paling dominan dalam penentuan status pencemaran adalah COD. Dengan demikian, perairan Situ Gunung Putri kurang mendukung untuk kegiatan perikanan karena parameter kualitas air COD dan DO di Stasiun 3 dan 5 tidak memenuhi syarat baku mutu air kelas II dan III berdasarkan Peraturan Pemerintah Nomor 82 Tahun 2001. Baik limbah industri, domestik, maupun pertanian yang masuk ke perairan Situ Gunung Putri berkontribusi terhadap pencemaran lingkungan perairan yang dapat dilihat dari nilai COD yang tinggi.
\end{abstract}

Kata kunci: kualitas air, pencemaran, metode STORET, Indeks Pencemaran, Situ Gunung Putri 


\begin{abstract}
Pollution Status of Gunung Putri Pond in Bogor Regency Based on STORET Method and Pollution Index. Gunung Putri pond located in Bogor Regency functions as water reservoir, agricultural irrigation, fisheries activities, as well as domestic and industrial waste disposal sites. Human activities around the pond are thought to cause a decrease in the physical, chemical and biological qualities of the pond water. Therefore, research on the pollution status needs to be carried out for the management of pond water resources. The purpose of this study was to determine the status of Gunung Putri pond pollution as measured by the physical and chemical parameters of its waters. The study was conducted from February to March 2019. The methods used in determining the status of pollution were the STORET method and the Pollution Index (IP). The results of water quality measurements carried out in the field were compared with water quality standards, and were used in determining the status of pollution according to each method. Both methods produce different water quality status for each station, with the STORET method score ranging -20-0 and the Pollution Index score ranging 0.31-3.92. The STORET method more accurately explained the pollution conditions in Gunung Putri pond and showed that the water was in mild to moderate polluted conditions. Based on the two methods used, the highest pollution status was found at Stations 3 and 5. Organic material with high content was suspected as the cause of pollution because the most dominant water quality parameter in determining pollution status was COD. Therefore, Gunung Putri pond cannot support fishery activities because the water quality parameters of COD and DO at Stations 3 and 5 do not meet the water quality standards for the class II and III waters based on the Government Regulation No. 82 of 2001. Industrial, domestic, and agricultural wastes entering the waters of Gunung Putri pond contribute to the pollution of the aquatic environment which can be seen from the high COD value.
\end{abstract}

Keywords: water quality, pollution, STORET method, Pollution Index, Gunung Putri pond

\section{Pendahuluan}

Penelitian yang mengkaji kualitas air maupun pengelolaan situ belum cukup banyak, sementara jumlah situ yang mengalami kerusakan semakin meningkat. Berdasarkan pengamatan di lapangan menggunakan interpretasi kondisi situ secara visual dan data pengindraan jauh, di Kabupaten Bogor terdapat 106 situ, namun yang bisa teridentifikasi berjumlah 101 situ dengan kondisi 23 rusak, 26 sedang, dan 52 baik (Suryanta, 2016). Kerusakan yang terjadi di situ-situ Kabupaten Bogor tersebut umumnya berupa penurunan daya tampung air yang disebabkan oleh penurunan luas dan sedimentasi. Menurut Elfidasari et al. (2015), Situ Lebak Wangi, salah satu situ di Kabupaten Bogor, mengalami penurunan debit air akibat sedimentasi. Hal tersebut disebabkan terjadi peningkatan aktivitas masyarakat yang memanfaatkan situ sebagai tempat pembuangan limbah. Masukan beban limbah organik dan nonorganik dapat menyebabkan algae blooming dan mengubah faktor fisika dan kimia lingkungan perairan.

Situ Gunung Putri merupakan salah satu situ di Kabupaten Bogor yang memiliki luas $120.645 \mathrm{~m}^{2}$ serta kedalaman berkisar 0,5-1,7 m. Situ dikelilingi oleh area permukiman, lahan pertanian, dan beberapa industri yang membuang limbahnya ke badan air situ, antara lain industri manufaktur motor, pemasok peralatan industri, industri otomotif, dan perusahaanperusahaan konstruksi yang secara langsung maupun tidak langsung mencemari perairan situ. Awalnya, Situ Gunung Putri dimanfaatkan oleh masyarakat sebagai penampung air, sumber 
irigasi pertanian, dan kegiatan perikanan tangkap. Namun, seiring dengan waktu situ ini juga dimanfaatkan sebagai tempat pembuangan limbah, baik domestik maupun industri. Limbah-limbah tersebut masuk ke perairan situ melalui saluran air dan sungai kecil. Menurut penduduk setempat, saluran-saluran air tersebut sering kali mengeluarkan cairan berwarna hitam dan berbau tidak sedap ke dalam perairan situ. Aktivitas masyarakat di sekitar situ telah menyebabkan penurunan kualitas fisika, kimia, dan biologi perairan situ, terlihat dari kedalaman yang dangkal dengan dasar berlumpur, air tampak keruh, bau tidak sedap, serta sampah plastik yang banyak ditemukan di sekitar inlet, outlet, maupun yang terjebak dan terbawa oleh tumbuhan air. Eutrofikasi atau penyuburan perairan diduga telah terjadi di Situ Gunung Putri yang dibuktikan oleh keberadaan populasi tumbuhan air eceng gondok dan teratai yang tumbuh menutupi kurang lebih setengah permukaan situ dalam jangka waktu yang lama.

Metode STORET dan Indeks Pencemaran merupakan metode yang populer digunakan di Indonesia. Metodemetode tersebut memberikan fleksibilitas penggunaan jumlah dan jenis parameter kualitas air serta pemakaian regulasi baku mutu sesuai kebutuhan lokal. Bentuk persamaan dan simulasi sensitivitas indeks dikaji berdasarkan penggunaan banyak parameter dengan dan tanpa parameter bakteriologi (Total Coli dan E. coli), dan penggunaan hanya beberapa parameter kualitas air seperti dalam metode Overall Index Pollution (OIP) yang diterapkan di India dan metode Interim National Water Quality Standards-Department of Environmental (INWQS-DOE) yang diterapkan di Malaysia. Indeks OIP dan DOE adalah metode indeks kualitas air yang dikembangkan dengan standar lingkungan masing-masing di India dan Malaysia, yang memiliki tantangan polusi domestik dan industri mirip dengan Indonesia (Saraswati et al., 2014).
Masing-masing metode mempunyai kelebihan dan kelemahan yang menjadi pertimbangan pemilihan metode-metode tersebut. Metode STORET mempunyai kelebihan dapat menyimpulkan status mutu air pada rentang waktu tertentu, sehingga mudah dipahami oleh masyarakat awam. Kelemahan metode ini adalah memerlukan beberapa seri data yang cukup dalam penentuan kualitas air, sehingga memerlukan biaya yang relatif lebih besar dan waktu yang lebih panjang. Metode Indeks Pencemaran mempunyai kelebihan dapat menentukan status mutu air yang dipantau hanya dengan satu seri data, sehingga memerlukan biaya dan waktu yang relatif sedikit. Kelemahannya adalah karena data yang dihitung adalah data tunggal, maka sering terjadi data tunggal tersebut tidak cukup mewakili kondisi kualitas perairan yang sebenarnya (Yusrizal, 2015).

Dengan metode STORET, parameterparameter yang telah memenuhi atau melampaui baku mutu air dapat diketahui. Penilaian tingkat kualitas air dengan metode STORET tidak bergantung pada jumlah dan jenis parameter yang harus digunakan. Selama parameter kualitas air yang diteliti dapat dibandingkan dengan baku mutu yang ada, maka indeks tingkat kualitasnya dapat ditentukan (Hariyadi \& Effendi, 2016 dalam Kadim et al., 2017).

Indeks Pencemaran (IP) digunakan untuk menentukan tingkat pencemaran relatif terhadap parameter kualitas air yang diizinkan. IP dapat memberi masukan kepada pengambil keputusan agar dapat menilai kualitas badan air untuk suatu peruntukan, serta melakukan tindakan untuk memperbaiki kualitas jika terjadi penurunan akibat kehadiran senyawa pencemar. IP mencakup berbagai kelompok parameter kualitas yang independen dan bermakna (Keputusan Menteri Negara Lingkungan Hidup No. 115 Tahun 2003). Metode IP sering digunakan bersamaan dengan metode STORET sebagai perbandingan penentuan status mutu air menggunakan parameter kualitas air yang 
sama. Penggunaan kedua metode ini dapat menghasilkan output yang berbeda karena ada pembobotan tiap-tiap parameter yang berbeda (Huboyo et al., 2009).

Sebagai metode berbasis indeks, metode Indeks Pencemaran dibangun berdasarkan dua indeks kualitas. Yang pertama adalah indeks rata-rata $\left(I_{R}\right)$ yang menunjukkan tingkat pencemaran rata-rata dari seluruh parameter dalam satu kali pengamatan. Yang kedua adalah indeks maksimum $\left(\mathrm{I}_{\mathrm{M}}\right)$ yang menunjukkan satu jenis parameter dominan yang menyebabkan penurunan kualitas air pada satu kali pengamatan (Marganingrum et al., 2013).

Dalam penelitian ini, status pencemaran Situ Gunung Putri ditentukan dengan mengukur parameter fisika dan kimia perairannya. Penelitian ini diharapkan dapat memberikan informasi mengenai kondisi pencemaran di perairan Situ Gunung Putri dan bahan-bahan pencemar yang sudah dan berpotensi menurunkan kualitas perairan situ, sehingga pencemaran Situ Gunung Putri dapat diatasi dan situ dapat dikelola dengan baik sesuai peruntukannya.

\section{Bahan dan Metode}

Penelitian dilaksanakan dari bulan Februari sampai dengan Maret 2019 di Situ Gunung Putri, Desa Gunung Putri, Kecamatan Gunung Putri, Kabupaten Bogor. Metode yang digunakan dalam penentuan status pencemaran yaitu metode STORET dan Indeks Pencemaran berdasarkan Keputusan Menteri Lingkungan Hidup Nomor 115 Tahun 2003 tentang Pedoman Penentuan Status Mutu Air. Kedua metode tersebut dapat menentukan kelas kualitas air melalui perbandingan parameter dengan baku mutu yang telah ditetapkan sesuai Peraturan Pemerintah Nomor 82 Tahun 2001 tentang Pengelolaan Kualitas Air dan Pengendalian Pencemaran Air. Parameter kualitas air yang digunakan dalam kedua metode tersebut diperlihatkan dalam Tabel 1 .

\section{Penentuan Titik Sampling}

Pengambilan sampel air dilakukan di lima stasiun penelitian (Gambar 1, Tabel 2). Titik pengambilan sampel ditentukan berdasarkan aktivitas masyarakat di sekitarnya yang memungkinkan beban pencemar masuk ke perairan Situ Gunung Putri. Dari setiap stasiun, sampel air diambil sebanyak $250 \mathrm{~mL}$ untuk masingmasing pengujian COD, nitrat, amonia, dan fosfat. Pengawet asam sulfat ditambahkan ke dalam sampel air untuk pengujian COD dan amonia, kemudian sampel dimasukkan ke dalam cool box dan dibawa ke Laboratorium Produktivitas dan Lingkungan Perairan (Proling) IPB, sedangkan sampel air untuk pengujian nitrat dan fosfat dimasukkan ke dalam cool box, kemudian dibawa ke Laboratorium Pusat Penelitian Limnologi LIPI.

Tabel 1. Parameter kualitas air yang diukur

\begin{tabular}{lcc}
\hline \multicolumn{1}{c}{ Parameter } & Alat/Metode & Lokasi pengamatan \\
\hline Parameter Fisika & & \\
\hline Suhu $\left({ }^{\circ} \mathrm{C}\right)$ & Water Quality Checker Horiba & In situ \\
\hline Parameter Kimia & \\
\hline $\mathrm{pH}$ & Water Quality Checker Horiba & In situ \\
$\mathrm{DO}(\mathrm{mg} / \mathrm{L})$ & Water Quality Checker Horiba & In situ \\
$\mathrm{COD}(\mathrm{mg} / \mathrm{L})$ & Metode Refluks Tertutup & Laboratorium \\
Nitrat $(\mathrm{mg} / \mathrm{L})$ & Metode Brucine & Laboratorium \\
Amonia $(\mathrm{mg} / \mathrm{L})$ & Metode Fenat & Laboratorium \\
Fosfat $(\mathrm{mg} / \mathrm{L})$ & Metode Asam Askorbat & Laboratorium \\
\hline
\end{tabular}




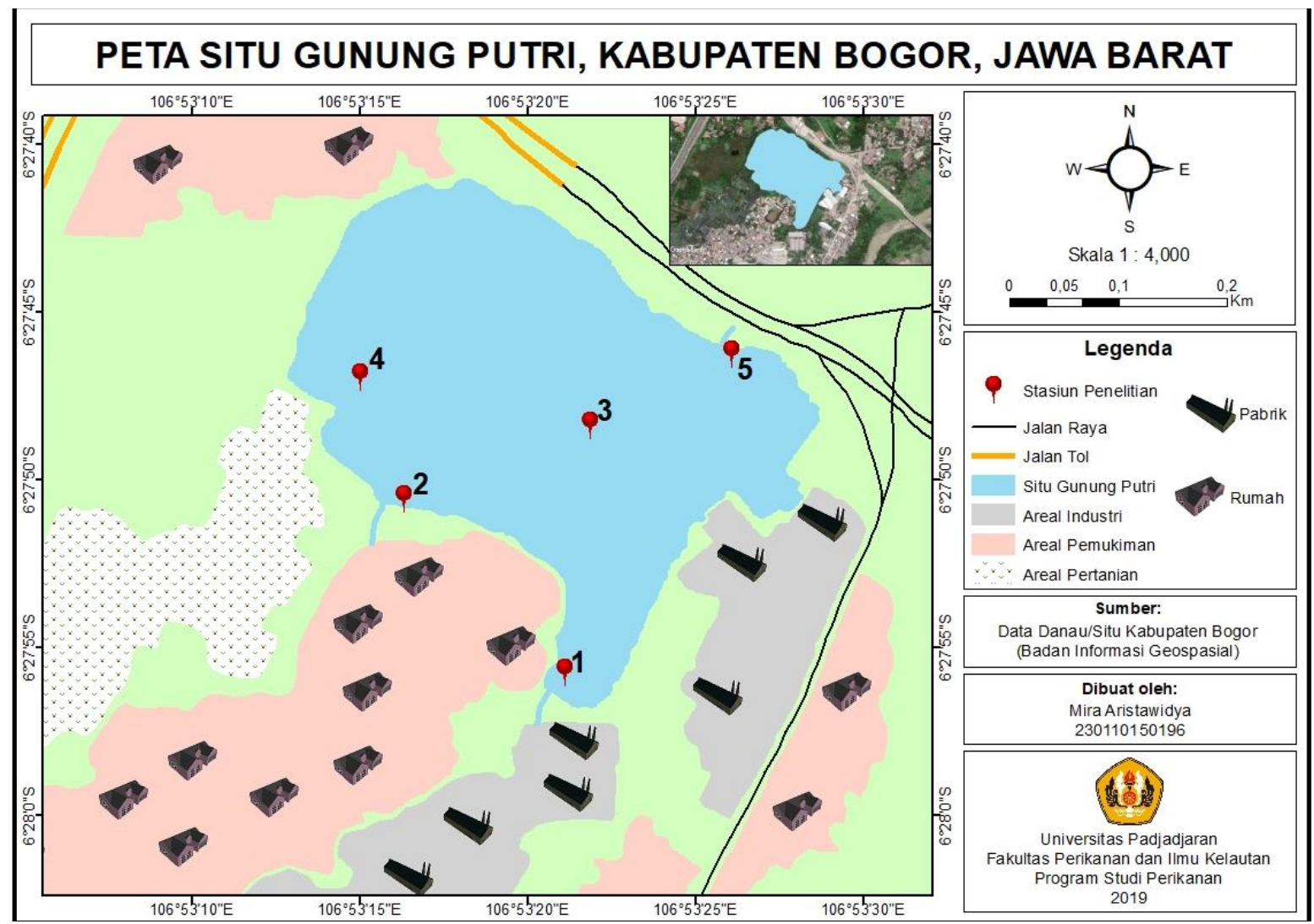

Gambar 1. Lokasi sampling di Situ Gunung Putri

Tabel 2. Lokasi dan karakteristik lima stasiun sampling di Situ Gunung Putri

\begin{tabular}{|c|c|c|}
\hline Stasiun & Koordinat & Keterangan \\
\hline 1 & $6^{\circ} 27^{\prime} 55,68^{\prime \prime}$ LS dan $106^{\circ} 53^{\prime} 21,00^{\prime \prime} \mathrm{BT}$ & Inlet dekat kawasan industri \\
\hline 2 & $6^{\circ} 27^{\prime} 50,52^{\prime \prime}$ LS dan $106^{\circ} 53^{\prime} 16,26^{\prime \prime} \mathrm{BT}$ & Inlet dekat kawasan permukiman \\
\hline 3 & $6^{\circ} 27^{\prime} 48,23^{\prime \prime}$ LS dan $106^{\circ} 53^{\prime} 21,83^{\prime \prime} \mathrm{BT}$ & Bagian tengah situ \\
\hline 4 & $6^{\circ} 27^{\prime} 46,86^{\prime \prime}$ LS dan $106^{\circ} 53^{\prime} 14,94^{\prime \prime} \mathrm{BT}$ & Inlet dekat kawasan pertanian \\
\hline 5 & $6^{\circ} 27^{\prime} 46,08^{\prime \prime}$ LS dan $106^{\circ} 53^{\prime} 26,10^{\prime \prime} \mathrm{BT}$ & Outlet situ \\
\hline
\end{tabular}

\section{Pengolahan Data dalam Metode STORET}

Pada analisis menggunakan metode STORET, data kualitas perairan dibandingkan dengan baku mutu yang sesuai dengan peruntukannya guna menentukan status mutu air. Hasil analisis per sampel air kemudian dibandingkan dengan baku mutu yang sesuai dengan pemanfaatan air (Hariono et al., 2017). Penentuan status mutu air dengan metode
STORET dilakukan dengan langkahlangkah sebagai berikut:

1. mengumpulkan data kualitas air dan debit air secara periodik untuk mendapatkan data dari waktu ke waktu (time series data) minimal 2 seri data

2. membandingkan data hasil pengukuran/pengujian dari masingmasing parameter air dengan nilai baku mutu sesuai dengan kelas air

3. jika pengukuran/pengujian memenuhi nilai baku mutu air (hasil pengukuran 
kurang daripada baku mutu), maka diberi skor 0

4. jika hasil pengukuran/pengujian tidak memenuhi nilai baku mutu air (hasil pengukuran lebih daripada baku mutu), maka diberi skor sesuai dengan Tabel 3

5. menghitung jumlah negatif dari seluruh parameter dan menentukan status mutu airnya dari jumlah skor yang didapat dengan menggunakan sistem nilai dari United States-Environmental Protection Agency (US-EPA) dengan mengklasifikasikan mutu air ke dalam empat kelas, yaitu:

Kelas A: baik sekali, skor 0, memenuhi baku mutu

Kelas B: baik, skor -1 s.d. -10 , tercemar ringan

Kelas C: sedang, skor -11 s.d. -30 , tercemar sedang

Kelas D: buruk, skor <-31, tercemar berat.

\section{Pengolahan Data dalam Metode Indeks Pencemaran}

Indeks kualitas air dengan metode Indeks Pencemaran dihitung dengan rumus sebagai berikut:

$$
\mathrm{PI}_{\mathrm{j}}=\sqrt{\frac{\left(\frac{\mathrm{C}_{\mathrm{i}}}{\mathrm{L}_{\mathrm{ij}}}\right)_{M}^{2}+\left(\frac{\mathrm{C}_{\mathrm{i}}}{\mathrm{L}_{\mathrm{ij}}}\right)^{2}}{2}}
$$

Keterangan:

$\mathrm{PI}_{\mathrm{j}} \quad$ : Indeks Pencemaran bagi peruntukan

$\mathrm{C}_{\mathrm{i}} \quad$ : Konsentrasi parameter kualitas air yang diperoleh dari hasil survei

$\mathrm{L}_{\mathrm{ij}} \quad$ : Konsentrasi parameter kualitas air yang dicantumkan dalam Baku Peruntukan Air

$\left(\mathrm{C}_{\mathrm{i}} / \mathrm{L}_{\mathrm{ij}}\right)_{\mathrm{M}}$ : Nilai $\mathrm{C}_{\mathrm{i}} / \mathrm{L}_{\mathrm{ij}}$ maksimum

$\left(\mathrm{C}_{\mathrm{i}} / \mathrm{L}_{\mathrm{ij}}\right)_{\mathrm{R}}$ : Nilai $\mathrm{C}_{\mathrm{i}} / \mathrm{L}_{\mathrm{ij}}$ rata-rata

Evaluasi terhadap nilai PI adalah:

$0 \leq \mathrm{PI}_{\mathrm{j}} \leq 1,0$ : memenuhi baku mutu

$1,0<\mathrm{PI}_{\mathrm{j}} \leq 5,0$ : tercemar ringan

$5,0<\mathrm{PI}_{\mathrm{j}} \leq 10$ : tercemar sedang

$\mathrm{PI}_{\mathrm{j}}>10$ : tercemar berat

\section{Hasil}

Data kualitas perairan yang diperoleh untuk menentukan status kualitas air Situ Gunung Putri adalah suhu, pH, COD, DO, konsentrasi nitrat, amonia, dan fosfat dalam air (Tabel 4).

Hasil pengukuran kualitas air dari tujuh parameter yang dibandingkan dengan baku mutu air kelas II dan III untuk perikanan menunjukkan bahwa parameter yang belum memenuhi syarat yaitu DO dan COD. Konsentrasi DO yang sudah memenuhi syarat baku mutu kelas II hanya ditemukan di Stasiun 1, sedangkan untuk Stasiun 2 dan 5 bahkan belum memenuhi

Tabel 3. Sistem nilai untuk parameter dan baku mutu metode STORET

\begin{tabular}{ccccc}
\hline \multirow{2}{*}{ Jumlah contoh* } & \multirow{2}{*}{ Nilai } & \multicolumn{3}{c}{ Parameter } \\
\cline { 3 - 5 } & & Fisika & Kimia & Biologi \\
\hline \multirow{3}{*}{$<10$} & Maksimum & -1 & -2 & -3 \\
& Minimum & -1 & -2 & -3 \\
& Rata-rata & -3 & -6 & -9 \\
\hline \multirow{3}{*}{$\geq 10$} & Maksimum & -2 & -4 & -6 \\
& Minimum & -2 & -4 & -6 \\
& Rata-rata & -6 & -12 & -18 \\
\hline
\end{tabular}

Keterangan:

* Jumlah contoh $=$ jumlah parameter yang digunakan untuk penentuan status mutu air 
Tabel 4. Kualitas perairan Situ Gunung Putri

\begin{tabular}{|c|c|c|c|c|c|c|c|c|}
\hline \multirow{2}{*}{\multicolumn{2}{|c|}{ Parameter }} & \multicolumn{5}{|c|}{ Stasiun } & \multicolumn{2}{|c|}{ PP No. 82 Tahun 2001} \\
\hline & & 1 & 2 & 3 & 4 & 5 & Kelas II & Kelas III \\
\hline \multirow{2}{*}{ Suhu $\left({ }^{\circ} \mathrm{C}\right)$} & $\mathrm{R}$ & $30,61 \pm 1,76$ & $29,54 \pm 1,12$ & $29,73 \pm 1,36$ & $28,58 \pm 0,77$ & $28,14 \pm 0,52$ & \multirow{2}{*}{ Deviasi 3} & \multirow{2}{*}{ Deviasi 3} \\
\hline & $\mathrm{K}$ & $28,63-32,90$ & $28,70-31,67$ & $28,40-32,30$ & $27,80-29,85$ & $27,60-28,98$ & & \\
\hline \multirow{2}{*}{$\mathrm{pH}$} & $\mathrm{R}$ & $7,25 \pm 0,23$ & $7,11 \pm 0,27$ & $7,27 \pm 0,10$ & $7,15 \pm 0,18$ & $7,33 \pm 0,34$ & \multirow{2}{*}{$6-9$} & \multirow{2}{*}{$6-9$} \\
\hline & $\mathrm{K}$ & $6,79-7,42$ & $6,74-7,49$ & $7,17-7,41$ & $7,01-7,49$ & $6,72-7,56$ & & \\
\hline \multirow{2}{*}{ COD (mg/L) } & $\mathrm{R}$ & $46,59 \pm 10,37$ & $46,89 \pm 13,33$ & $54,09 \pm 15,89$ & $42,22 \pm 9,86$ & $44,59 \pm 7,65$ & \multirow{2}{*}{$\leq 25$} & \multirow{2}{*}{$\leq 50$} \\
\hline & $\mathrm{K}$ & $29,55-61,83$ & $30,41-67,93$ & $35,56-75,92$ & $28,69-54,06$ & $35,13-54,02$ & & \\
\hline \multirow{2}{*}{$\mathrm{DO}(\mathrm{mg} / \mathrm{L})$} & $\mathrm{R}$ & $5,70 \pm 2,55$ & $2,81 \pm 1,38$ & $3,96 \pm 3,73$ & $3,06 \pm 2,69$ & $1,92 \pm 1,10$ & \multirow{2}{*}{$\geq 4$} & \multirow{2}{*}{$\geq 3$} \\
\hline & $\mathrm{K}$ & $3,53-9,56$ & $1,07-4,44$ & $0,92-10,41$ & $0,65-8,32$ & $0,56-3,07$ & & \\
\hline \multirow{2}{*}{ Nitrat (mg/L) } & $\mathrm{R}$ & $0,049 \pm 0,006$ & $0,058 \pm 0,015$ & $0,050 \pm 0,009$ & $0,047 \pm 0,009$ & $0,049 \pm 0,007$ & \multirow{2}{*}{$\leq 10$} & \multirow{2}{*}{$\leq 20$} \\
\hline & $\mathrm{K}$ & $0,041-0,056$ & $0,039-0,077$ & $0,036-0,061$ & $0,036-0,057$ & $0,035-0,057$ & & \\
\hline \multirow{2}{*}{$\begin{array}{l}\text { Amonia } \\
(\mathrm{mg} / \mathrm{L})\end{array}$} & $\mathrm{R}$ & $0,653 \pm 0,333$ & $0,796 \pm 0,306$ & $0,610 \pm 0,306$ & $0,827 \pm 0,490$ & $0,644 \pm 0,431$ & \multirow{2}{*}{\multicolumn{2}{|c|}{$\begin{array}{l}\text { Kandungan amonia bebas } \\
\text { untuk ikan yang peka: } \leq \\
0,02 \mathrm{mg} / \mathrm{L}\end{array}$}} \\
\hline & $\mathrm{K}$ & $0,113-0,963$ & $0,266-1,065$ & $0,233-1,122$ & $0,204-1,696$ & $0,090-1,188$ & & \\
\hline \multirow{2}{*}{$\begin{array}{l}\text { Fosfat } \\
(\mathrm{mg} / \mathrm{L})\end{array}$} & $\mathrm{R}$ & $0,018 \pm 0,005$ & $0,017 \pm 0,003$ & $0,015 \pm 0,002$ & $0,022 \pm 0,004$ & $0,015 \pm 0,003$ & \multirow{2}{*}{$\leq 0,2$} & \multirow{2}{*}{$\leq 1,0$} \\
\hline & $\mathrm{K}$ & $0,013-0,027$ & $0,014-0,023$ & $0,012-0,018$ & $0,015-0,025$ & $0,012-0,019$ & & \\
\hline
\end{tabular}

Keterangan:

$\mathrm{R}=$ rata-rata

$\mathrm{K}=$ kisaran 
syarat baku mutu kelas III. Nilai COD di semua stasiun belum memenuhi syarat baku mutu kelas II, sedangkan untuk baku mutu kelas III hanya Stasiun 3 yang sudah memenuhi syarat. Hasil pengukuran amonia di setiap stasiun penelitian menunjukkan rata-rata yang cukup tinggi, tetapi baku mutu kualitas air kelas II dan III dalam PP Nomor 82 Tahun 2001 menjelaskan bahwa tidak disyaratkan batas maksimum amonia untuk kegiatan perikanan, kecuali bagi ikan yang peka, yakni $\leq 0,02 \mathrm{mg} / \mathrm{L}$.

Analisis status pencemaran menurut metode STORET dan Indeks Pencemaran menggunakan perbandingan hasil pengukuran kualitas air dengan baku mutu air dari kelas I hingga kelas IV. Kedua metode menghasilkan status kualitas air yang berbeda untuk masing-masing stasiun. Perbandingan hasil penentuan status pencemaran antara metode STORET dan Indeks Pencemaran diperlihatkan dalam Tabel 5.

\section{Pembahasan}

Penilaian menurut metode STORET dan Indeks Pencemaran dilakukan dengan membandingkan tujuh parameter kualitas air dengan baku mutu air kelas II dan III untuk perikanan yang diperlihatkan dalam Tabel 4. Kedalaman yang dangkal, sekitar 50-60 cm, dan dasar berlumpur di Stasiun 1 menyebabkan perairan tampak lebih keruh dibandingkan stasiun yang lain. Stasiun 1 juga mengeluarkan bau tidak sedap yang diduga berasal dari buangan limbah industri. Di stasiun ini tidak ada makrofita maupun tutupan yang menghalangi cahaya matahari ke permukaan air, sehingga suhu yang terukur sedikit lebih tinggi dibanding stasiun lain. Sebaliknya, permukaan air di Stasiun 2 banyak ditumbuhi oleh tanaman air eceng gondok yang diduga diakibatkan oleh pengayaan unsur hara yang berasal dari limbah domestik. Hal ini terlihat dari konsentrasi nitrat rata-rata tertinggi diperoleh di Stasiun 2 yang merupakan inlet dekat kawasan permukiman.

Permukaan air di Stasiun 4 juga banyak ditumbuhi oleh eceng gondok, namun Stasiun 4 yang berlokasi di sekitar kawasan pertanian ini tidak memiliki inlet yang pasti. Stasiun 4 diduga mendapatkan run off dari aktivitas pertanian yang memungkinkan masukan material organik berupa pupuk dan serasah. Oleh karena itu,

Tabel 5. Status pencemaran menurut metode STORET dan Indeks Pencemaran

\begin{tabular}{cccccccccc}
\hline \multirow{2}{*}{ Stasiun } & \multicolumn{2}{c}{ Kelas I } & \multicolumn{2}{c}{ Kelas II } & \multicolumn{2}{c}{ Kelas III } & \multicolumn{2}{c}{ Kelas IV } \\
\cline { 2 - 9 } & STORET & IP & STORET & IP & STORET & IP & STORET & IP \\
\hline 1 & -18 & 3,37 & -12 & 1,35 & -2 & 0,68 & 0 & 0,34 \\
2 & -20 & 3,41 & -18 & 1,38 & -10 & 0,69 & 0 & 0,34 \\
3 & -18 & 3,92 & -12 & 1,58 & -10 & 0,79 & 0 & 0,39 \\
4 & -18 & 3,08 & -18 & 1,24 & -4 & 0,63 & 0 & 0,31 \\
5 & -20 & 3,25 & -20 & 1,31 & -10 & 0,67 & 0 & 0,33 \\
\hline
\end{tabular}

Keterangan :

Kelas A: baik sekali, memenuhi baku mutu
Kelas B: baik, tercemar ringan
Kelas C: sedang, tercemar sedang
Kelas D: buruk, tercemar berat


konsentrasi fosfat rata-rata tertinggi yang didapatkan di stasiun ini sangat terkait dengan masukan nutrien berupa pupuk, baik melalui saluran air maupun erosi tanah yang berasal dari kawasan pertanian.

Stasiun 3 yang merupakan bagian tengah situ memiliki kedalaman paling dalam, yakni sekitar 0,9-1,7 m. Stasiun ini memiliki kondisi air yang keruh, ditumbuhi teratai dan sebagian besar eceng gondok, serta banyak ditemukan sampah plastik yang terjebak dan terbawa oleh tumbuhan air. Sebagai bagian yang mendapatkan pengaruh dari stasiun-stasiun di inlet, Stasiun 3 memiliki nilai COD rata-rata tertinggi. Stasiun 5 yang merupakan outlet situ banyak ditumbuhi oleh teratai. Sampah-sampah yang masuk ke badan perairan terlihat bertumpuk di sekitar pintu air. Di sekitar Stasiun 5 terdapat pohonpohon rindang yang menyebabkan badan perairan tertutup oleh bayangan pohonpohon tersebut, sehingga suhu rata-rata yang didapatkan di Stasiun 5 terendah. Meskipun sebagai stasiun outlet yang seharusnya juga mendapat pengaruh dari stasiun di bagian hulu, di Stasiun 5 nilai COD yang didapatkan tidak sebesar nilai COD di Stasiun 3. Namun, konsentrasi DO rata-rata terendah didapatkan di stasiun ini, yang akan memengaruhi nilai skor dalam analisis status kualitas air menggunakan metode STORET dan Indeks Pencemaran.

Perbedaan antara metode STORET dan Indeks Pencemaran adalah dari penentuan nilai atau skor yang dijadikan rujukan. Metode STORET menggunakan skala nilai -31 sampai 0 , sedangkan metode Indeks Pencemaran menggunakan skor 0 sampai 10 (Sahabuddin et al., 2014). Selain itu, perbedaan kedua metode ini kemungkinan disebabkan oleh prinsip analisis yang berbeda. Indeks STORET didasarkan atas subjektivitas bobot dan skor parameter yang dianggap signifikan. Bobot parameter biologi dianggap tiga kali lebih penting dan parameter kimia dua kali lebih penting dibanding parameter fisika. Kemudian, bobot masing-masing parameter tersebut diberi nilai dua kali lebih besar jika parameter signifikan untuk menghitung indeks berjumlah > 10. Indeks STORET dihitung berdasarkan nilai maksimum, minimum, dan rerata dari data beberapa pengambilan sampel kualitas air. Semakin banyak parameter kualitas air yang diukur akan semakin terpantau parameter yang tidak memenuhi baku mutu (dari nilai maksimum dan minimum parameter), dan semakin sering parameter tersebut tidak memenuhi ambang batas akan semakin buruk status mutu airnya (Saraswati et al., 2014). Namun, indeks STORET sangat dipengaruhi oleh bobot parameter biologi dibandingkan parameter kimia dan fisika, sehingga ketiadaan parameter biologi dalam penghitungan akan sangat berdampak pada hasil penentuan status pencemaran.

Pada Indeks Pencemaran tidak ada skema skor subindeks atau skor definitif (subjektif) per parameter, dan parameter paling signifikan dihitung atas dasar perbandingan terbesar dari konsentrasi terhadap baku mutunya. Berbanding terbalik dengan STORET, baik dengan sedikit ataupun banyak parameter kualitas air, Indeks Pencemaran tidak cukup sensitif membedakan kelas status mutu air. Hal ini dikarenakan dalam metode Indeks Pencemaran yang dianggap penting dalam menentukan skor adalah suatu parameter yang mempunyai $\left(\mathrm{C}_{\mathrm{i}} / \mathrm{L}_{\mathrm{ij}}\right)$ maksimum, dibanding rerata semua parameter kualitas airnya. Metode Indeks Pencemaran dihitung dengan mempertimbangkan rasio konsentrasi suatu parameter dengan baku mutunya, nilai maksimum, dan nilai rerata rasio sejumlah parameter kualitas air, hanya dari satu waktu kegiatan pengambilan sampel kualitas air. Pengukuran dengan data tunggal yang lain (waktu yang berlainan), di lokasi yang sama sering kali menghasilkan status mutu air yang berbeda. Hal ini menyebabkan perbedaan interpretasi mengenai status kualitas air yang dipantau, sehingga dapat menimbulkan kerancuan atau perbedaan penafsiran bagi masyarakat awam (Yusrizal, 2015). 
Hasil analisis kedua metode yang digunakan (Tabel 5) menunjukkan bahwa status mutu air untuk masing-masing stasiun pengamatan di Situ Gunung Putri telah tercemar ringan hingga sedang. Skor mutu air yang tinggi atau rendah dipengaruhi oleh beban pencemar yang masuk ke badan air akibat aktivitas antropogenik yang ada di sekitarnya. Menurut Walukow (2010), kegiatan yang dominan memengaruhi mutu air antara lain permukiman, pertanian, industri, erosi dan faktor alamiah kandungan tanah di sekitar badan air. Meskipun hasil analisis kualitas air di setiap stasiun merata untuk setiap kelas, namun di beberapa stasiun didapatkan skor yang menunjukkan kondisi kualitas perairan paling buruk. Berdasarkan metode STORET, skor tertinggi ditemukan di Stasiun 5, sedangkan berdasarkan Indeks Pencemaran skor tertinggi terdapat di Stasiun 3. Hal ini dimungkinkan karena di Stasiun 3 dan 5 beban pencemar dari sekitar situ sudah tercampur dan terakumulasi yang selanjutnya terbawa arus menuju outlet (Stasiun 5).

Parameter yang paling dominan dalam pengukuran kualitas air di Situ Gunung Putri adalah COD. Nilai COD menggambarkan jumlah total bahan organik yang ada di perairan. Nilai COD yang tinggi menunjukkan bahwa jumlah oksigen yang banyak dibutuhkan untuk mengoksidasi bahan organik dalam air tersebut. Nilai COD yang didapatkan selama penelitian berkisar 28,69-75,92 $\mathrm{mg} / \mathrm{L}$, dengan rata-rata tertinggi terdapat di Stasiun 3 yakni 54,09 mg/L. Hal ini diduga disebabkan terjadi penumpukan bahan pencemar dari semua inlet ke bagian tengah Situ Gunung Putri. Perbedaan nilai COD di setiap stasiun pengamatan dapat dipengaruhi oleh masukan beban pencemar yang berbeda-beda. Nilai COD di Stasiun 1 lebih tinggi daripada di Stasiun 4 yang dapat disebabkan oleh masukan beban pencemar di Stasiun 1 yang lebih besar, mengingat Stasiun 1 merupakan inlet dari kawasan industri. Selain itu, perbedaan nilai COD tersebut juga dapat dikarenakan bahan organik di Stasiun 4 dimanfaatkan untuk pertumbuhan makrofita. Nilai COD akan meningkat dengan peningkatan bahan organik yang terdapat di perairan.

Nilai COD perairan akan berpengaruh terhadap nilai oksigen terlarut di perairan tersebut karena COD merupakan jumlah oksigen yang diperlukan untuk mengurai dan mengoksidasi seluruh bahan organik yang terkandung dalam air. COD yang terkandung dalam perairan juga dapat memengaruhi keberadaan fitoplankton dan menurunkan konsentrasi oksigen terlarut. Nilai COD yang masih dapat ditoleransi oleh fitoplankton bisa meningkatkan jumlah fitoplankton yang terdapat di perairan karena hasil oksidasi bahan organik yang berupa bahan anorganik $\left(\mathrm{CO}_{2}\right)$ dimanfaatkan oleh fitoplankton sebagai makanannya. Namun, nilai COD yang tinggi juga dapat menjadikan beberapa parameter kualitas air yang mendukung kehidupan fitoplankton seperti DO dan $\mathrm{pH}$ menjadi tidak baik bagi kelangsungan hidup fitoplankton (Mayagitha et al., 2014). DO yang terukur selama penelitian berkisar 0,56-10,41 $\mathrm{mg} / \mathrm{L}$, dengan kandungan rata-rata tertinggi sebesar 5,70 mg/L di Stasiun 1. Hal ini dimungkinkan karena hanya di Stasiun 1 badan air tidak tertutup oleh makrofita, sehingga difusi oksigen dari udara lebih besar dibandingkan dengan stasiun yang lain. Sebaliknya, konsentrasi DO di Stasiun 3 cukup baik meskipun nilai COD yang didapatkan juga tinggi. Hal ini diduga dikarenakan terjadi pemanfaatan karbondioksida sebagai hasil proses oksidasi bahan organik untuk fotosintesis fitoplankton dan tumbuhan air.

Hasil penentuan status pencemaran, baik berdasarkan metode STORET maupun Indeks Pencemaran, menunjukkan bahwa dari tiga inlet di Situ Gunung Putri, Stasiun 2 yang merupakan inlet dekat kawasan permukiman memberi kontribusi yang lebih banyak terhadap pencemaran di Situ Gunung Putri. Namun, baik kawasan industri, permukiman, maupun pertanian masih memberikan dampak yang nyata 
terhadap pencemaran perairan Situ Gunung Putri yang dapat dilihat dari nilai COD di tiga inlet tersebut yang belum memenuhi syarat baku mutu air kelas II untuk perikanan.

\section{Kesimpulan}

Kedua metode yang digunakan, yakni metode STORET dan Indeks Pencemaran menghasilkan status kualitas air yang berbeda untuk masing-masing stasiun. Dalam penelitian ini, metode STORET lebih akurat menjelaskan kondisi pencemaran Situ Gunung Putri yang menunjukkan situ dalam keadaan tercemar ringan hingga sedang. Hal ini diketahui dari parameter kualitas air COD dan DO yang tidak memenuhi syarat baku mutu air kelas II dan III untuk perikanan. Baik limbah industri, domestik, maupun pertanian yang masuk ke perairan Situ Gunung Putri berkontribusi terhadap pencemaran lingkungan perairan yang dapat dilihat dari nilai COD yang tinggi dalam pengukuran kualitas air.

\section{Ucapan Terima Kasih}

Penulis mengucapkan terima kasih kepada seluruh pihak yang telah memberikan saran dan bimbingan dalam pembuatan makalah ilmiah ini. Terima kasih juga penulis ucapkan kepada keluarga besar Fakultas Perikanan dan Kelautan Universitas Padjadjaran, keluarga besar Pusat Penelitian Limnologi LIPI, serta teman-teman yang tidak dapat penulis sebutkan satu persatu atas segala bantuan yang telah diberikan.

\section{Referensi}

Elfidasari D, Noriko N, Effendi Y, Puspitasari RL. 2015. Kualitas Air Situ Lebak Wangi Bogor Berdasarkan Analisa Fisika, Kimia dan Biologi.
Jurnal Al-Azhar Indonesia Seri Sains dan Teknologi 3(2): 104-112

Hariono B, Riskiawan HY, Sugiyarto, Anwar S. 2017. Penentuan Status Mutu Air Metode STORET DAS Kalibaru. Prosiding Sentrinov Tahun 2017, 31-40

Huboyo HS, Nugraha WD, Indah RR. 2009. Analisis Penentuan Mutu Air Beberapa Sungai di Jawa Tengah dengan Metode STORET dan Indeks Pencemaran. Jurnal PRESIPITASI 6(2): 1-8

Kadim MK, Pasisingi N, Paramata AR. 2017. Kajian Kualitas Perairan Teluk Gorontalo dengan Menggunakan Metode STORET. Depik Jurnal IlmuIlmu Perairan, Pesisir dan Perikanan 6(3): 235-241. DOI: 10.13170/depik.6.3.8442

Keputusan Menteri Negara Lingkungan Hidup Nomor 115 Tahun 2003 tentang Pedoman Penentuan Status Mutu Air

Marganingrum D, Roosmin D, Pradono, Sabar A. 2013. Diferensiasi Sumber Pencemar Sungai Menggunakan Pendekatan Metode Indeks Pencemar (IP) (Studi Kasus: Hulu DAS Citarum). Jurnal RISET Geologi dan Pertambangan 23(1): 37-48

Mayagitha KA, Haeruddin, Rudiyanti S. 2014. Status Kualitas Perairan Sungai Bremi Kabupaten Pekalongan Ditinjau dari Konsentrasi TSS, BOD5, COD dan Struktur Komunitas Fitoplankton. Diponegoro Journal of Maquares 3(1): 177-185

Peraturan Pemerintah Republik Indonesia Nomor 82 Tahun 2001 tentang Pengelolaan Kualitas Air dan Pengendalian Pencemaran Air

Sahabuddin H, Harisuseno D, Yuliani E. 2014. Analisa Status Mutu Air dan Daya Tampung Beban Pencemaran Sungai Wanggu Kota Kendari. Jurnal Teknik Pengairan 5(1): 19-28

Saraswati SP, Sunyoto, Kironoto BA, Hadisusanto S. 2014. Kajian Bentuk dan Sensitivitas Rumus Indeks PI, STORET, CCME untuk Penentuan Status Mutu Perairan Sungai Tropis di Indonesia. 
Jurnal Manusia dan Lingkungan 21(2): 129-142

Suryanta J. 2016. Kualitas Situ di Kabupaten Bogor Berdasar Interpretasi Data Satelit Pengindraan Jauh serta Pengaruhnya dalam Pengendalian Banjir Sungai Ciliwung. Prosiding Seminar Nasional Geografi UMS Tahun 2016, 521-533
Walukow AF. 2010. Penentuan Status Mutu Air dengan Metode STORET di Danau Sentani Jayapura Provinsi Papua. Jurnal Berita Biologi 10(3): 277-281

Yusrizal H. 2015. Efektivitas Metode Perhitungan STORET, IP dan CCME WQI dalam Menentukan Status Kualitas Air Way Sekampung Provinsi Lampung. Tesis. Universitas Lampung 